Security Arabic 


\title{
Books in the series
}

\author{
Media Persian \\ Dominic Parviz Brookshaw \\ Internet Arabic \\ Mourad Diouri \\ Security Arabic \\ Mark Evans \\ Media Arabic \\ 2nd edition \\ Elisabeth Kendall
}

www.euppublishing.com/series/emev 
- Essential Middle Eastern Vocabularies •

\section{Security Arabic}

Mark Evans

EDINBURGH

University Press 
(C) Mark Evans, 2013

Edinburgh University Press Ltd

22 George Square, Edinburgh

www.euppublishing.com

Typeset in Times New Roman and printed and bound in Great Britain by

CPI Group (UK) Ltd, Croydon CR0 4YY

A CIP record for this book is available from the British Library

ISBN 9780748646616 (paperback)

ISBN 9780748646630 (webready PDF)

ISBN 9780748649662 (epub)

ISBN 9780748649655 (Amazon ebook)

The right of Mark Evans to be identified as author of this work has been asserted in accordance with the Copyright, Designs and Patents Act 1988.

The e-Learning materials (audio recording and e-Flashcard sets) were produced by Mourad Diouri (e-Learning Lecturer/Developer in Arabic Studies, University of Edinburgh).

Published with the support of the Edinburgh University Scholarly Publishing Initiatives Fund. 